\title{
Feed additives for swine: Fact sheets - high dietary levels of copper and zinc for young pigs, and phytase
}

Jay Y. Jacela, DVM, PhD; Joel M. DeRouchey, PhD; Mike D. Tokach, PhD; Robert D. Goodband, PhD; Jim L. Nelssen, PhD; David G. Renter, DVM, PhD; Steve S. Dritz, DVM, PhD

This is the fourth in a series of peer-reviewed Practice tip articles, each including two or three fact sheets. Previous practice tips included fact sheets on acidifiers and antibiotics in the September-October issue ( $J$ Swine Health Prod. 2009;17:270-275); on carcass modifiers, carbohydrate-degrading enzymes, and proteases, and anthelmintics in the November-December issue ( $J$ Swine Health Prod. 2009;17:325-332); and on flavors and mold inhibitors, mycotoxin binders, and antioxidants in the January-February issue (J Swine Health Prod. 2010;18:27-32)

Future fact-sheet topics will include probiotics and prebiotics and phytogenic feed additives (phytobiotics or botanicals). 
Copper and zinc play important roles in many physiological processes. Dietary copper levels of 5 to $10 \mathrm{ppm}$ and zinc levels of 50 to $125 \mathrm{ppm}$ are generally enough to meet the pig's nutrient requirement for these processes. However, when supplied at high concentrations (100 to $250 \mathrm{ppm}$ for copper and 2000 to 3000 ppm for zinc), these two minerals are known to exert positive influences on growth rate. ${ }^{1}$ In addition, copper is efficacious even when antibiotics also are included in the diets. ${ }^{2}$ This suggests that the response to copper is additive to the response to antimicrobials. Response to high levels of dietary copper decreases with increasing age and with longer periods of administration. ${ }^{3}$

Zinc fed at high dietary levels (2000 to 3000 ppm) reduces incidence of diarrhea and increases weight gain in newly weaned pigs. ${ }^{4,5}$ However, these high levels of dietary zinc are beneficial to pigs only during the early phases of the nursery period. ${ }^{6}$ Thus, feeding period for high dietary levels of zinc should be limited to approximately 3 weeks after weaning. Additive effects are usually not observed in weaned pigs when high levels of copper and zinc are added together. However, the data is conflicting and this observation needs to be further investigated. ${ }^{4,6-8}$ Recent research has indicated that feeding high levels of zinc until pigs reached $12 \mathrm{~kg}$, then feeding high levels of copper for the remainder of the nursery period, was the most cost-effective strategy. ${ }^{6}$

\section{Mode of action for growth promotion at high dietary levels}

The mechanism by which high levels of copper and zinc improve growth rate in pigs is still unclear. Both have some antibacterial properties, ${ }^{9}$ which may explain the growth-promoting effect, but there is a lack of scientific evidence to understand the exact mode of action. The improvement in growth performance when the diet is supplemented with high levels of dietary copper is similar in magnitude to that achieved when in-feed antimicrobials are fed to nursery pigs. ${ }^{2}$ Even though copper has antibacterial properties, growth rate is stimulated in an additive manner when both antimicrobials and high levels of copper are added to nursery pig diets. ${ }^{2}$ Thus, it appears that the growth-promoting properties of high dietary levels of copper are in addition to its antimicrobial effect.

\section{What are the sources used for growth-promoting levels of copper and zinc?}

Most research on high levels of dietary copper has used copper sulfate. ${ }^{10}$ Increased growth rate has been demonstrated with the tri-basic chloride form as well. ${ }^{11}$ Limited information is available using other sources.

Increased growth rates when high levels of zinc are fed in the early postweaning period have been most consistently demonstrated with zinc provided as zinc oxide. ${ }^{4,8,12}$ Other sources, such as zinc sulfate and zinc methionine, have not consistently demonstrated positive effects. ${ }^{12,13}$

\section{Fast facts}

Copper and zinc are classified as trace minerals because they are required by pigs at relatively low levels for normal growth.

When added at high dietary levels, copper (100 to 250 ppm) and zinc (2000 to $3000 \mathrm{ppm}$ ) can increase the growth performance of young pigs.

The mechanisms by which high levels of copper and zinc improve growth rate in pigs is still unclear.

What are the potential problems with adding copper or zinc at these very high levels?

Copper toxicosis may occur when dietary levels exceed $250 \mathrm{ppm}$ for long periods. ${ }^{10}$ Jaundice (yellow discoloration of the skin) may result due to excessive accumulation of copper in the liver. Toxic effects of zinc, on the other hand, may be indicated by depressed pigs, arthritis, gastritis, and death. Zinc toxicosis has been reported when highly absorbable zinc sources, such as zinc carbonate, are added at up to $4000 \mathrm{ppm}$ for an extended period. ${ }^{10}$ To avoid these problems, it is important to use only the recommended dietary levels of copper and zinc for growth promotion at specific growing periods (Table 1).

It is also important to keep in mind that as more of these nutrients are added to the diet, the amount excreted by the animal also increases. Thus, the addition of copper and zinc at their growthpromoting levels can have negative repercussions in the environment because of high levels of these minerals being excreted through the feces, ${ }^{15,16}$ with resulting excessive accumulation of copper and zinc in the soils where the manure is applied.

Table 1: Recommended dietary levels of zinc and copper for pigs

\begin{tabular}{|c|c|c|}
\hline Production phase & Zinc (ppm) & Copper (ppm) \\
\hline \multicolumn{3}{|l|}{ Nursery } \\
\hline$<11 \mathrm{lb}$ & $3000^{*}$ & $5 \dagger$ \\
\hline $11-15 \mathrm{lb}$ & $3000^{*}$ & $5 \dagger$ \\
\hline $15-25 \mathrm{lb}$ & $2000^{*}$ & $5 \dagger$ \\
\hline $25-50 \mathrm{lb}$ & $50 \dagger$ & $100-250 \ddagger$ \\
\hline Grower $(50-120 \mathrm{lb})$ & $50 \dagger$ & $50-100 \ddagger$ \\
\hline Finisher (> $120 \mathrm{lb})$ & $50 \dagger$ & $5 \dagger$ \\
\hline
\end{tabular}

* Growth-promotion levels. ${ }^{14}$

$\dagger$ Based on National Research Council minimum daily requirement. ${ }^{10}$

‡ Growth-promotion levels. ${ }^{3}$ 
Another negative effect of high dietary levels of copper is that the amount of unsaturated fat is increased, which results in a softer pork fat. ${ }^{17}$ Reducing dosages in finishing diets can minimize these negative impacts.

\section{Summary}

Copper and zinc are important trace minerals needed by the pig for numerous metabolic functions. Inclusions of these trace minerals at high dietary levels increases growth performance, especially in young pigs.

\section{References}

1. Hill GM, Spears JW. Trace and ultratrace elements in swine nutrition. In: Lewis AJ, Southern LL, eds. Swine Nutrition. 2nd ed. Boca Raton, Florida: CRC Press; 2001:229-261.

2. Cromwell GL. Antimicrobial and promicrobial agents. In: Lewis AJ, Southern LL, eds. Swine Nutrition. 2nd ed. Boca Raton, Florida: CRC Press; 2001:401-426.

3. Hastad CW, Dritz SS, Nelssen JL, Tokach MD, Goodband RD. Evaluation of different copper sources as a growth promoter in swine finishing diets. Kansas Agric Exp Sta Prog Rep 880. 2001;880:111-117. Available at: http://www. ksre.ksu.edu/library/lvstk2/srp8BØ.pdf. Accessed 6 January 2010.

4. Hill GM, Cromwell GL, Crenshaw TD, Dove CR, Ewan RC, Knabe DA, Lewis AJ, Libal GW, Mahan DC, Shurson GC, Southern LL, Veum TL. Growth promotion effects and plasma changes from feeding high dietary concentrations of zinc and copper to weanling pigs (regional study). J Anim Sci. 2000;78:1010-1016.

5. Holm A. Zinc oxide in treating E. coli diarrhea in pigs after weaning. Comp Cont Ed Pract Vet. 1996;18:S26-S48.

6. Shelton NW, Jacob ME, Tokach MD, Nelssen JL, Goodband RD, Dritz SS, DeRouchey JM, Amachawadi RG, Shi X, Nagaraja TG. Effects of copper sulfate, zinc oxide, and neoterramycin on weanling pig growth and antibiotic resistance rate for fecal Escherichia coli. Kansas Agric Exp Sta Prog Rep 1020.

2009;1020:73-79. Available at: http://www.ksre.ksu.edu/library/lvstk2/ srpl|■20.pdf. Accessed 4 December 2009.
7. Shelton NW, Tokach MD, Nelssen JL, Goodband RD, Dritz SS, DeRouchey JM, Hill GM. Effects of copper sulfate, tri-basic copper chloride, and zinc oxide on weanling pig growth and plasma mineral concentrations. Kansas Agric Exp Sta Prog Rep 1001. 2008:62-73. Available at: http://www.ksre.ksu. edu/library/lvstk2/srplabl.pdf. Accessed 4 December 2009.

8. Smith JW II, Tokach MD, Goodband RD, Nelssen JL, Richert BT. Effects of the interrelationship between zinc oxide and copper sulfate on growth performance of early-weaned pigs. J Anim Sci. 1997;75:1861-1866.

9. Dupont DP, Duhamel GE, Carlson MP, Mathiesen MR. Effect of divalent cations on hemolysin synthesis by Serpulina (Treponema) hyodysenteriae: inhibition induced by zinc and copper. Vet Microbiol. 1994;41:63-73.

10. National Research Council. Minerals. In: Nutrient Requirements of Swine. 10th ed. Washington, DC: National Academy Press; 1998:47-70.

11. Cromwell GL, Lindemann MD, Monegue HJ, Hall DD, Orr DE Jr. Tribasic copper chloride and copper sulfate as copper sources for weanling pigs. J Anim Sci. 1998;76:118-123.

12. Hahn JD, Baker DH. Growth and plasma zinc responses of young pigs fed pharmacologic levels of zinc. J Anim Sci. 1993;71:3020-3024.

13. van Heugten E, Spears JW, Kegley EB, Ward JD, Qureshi MA. Effects of organic forms of zinc on growth performance, tissue zinc distribution, and immune response of weanling pigs. J Anim Sci. 2003;81:2063-2071.

14. DeRouchey JM, Dritz SS, Goodband RD, Nelssen JL, Tokach MD. KSU Swine Nutrition Guide. Kansas State University, Manhattan. 2007. Available at: http://www.ksre.ksu.edu/library/lvstk2/MF2300.pdf. Accessed 4 December 2009.

15. Jondreville C, Revy PS, Dourmad JY. Dietary means to better control the environmental impact of copper and zinc by pigs from weaning to slaughter. Livest Prod Sci. 2003;84:147-156.

16. Carlson MS, Boren CA, Wu C, Huntington CE, Bollinger DW, Veum TL. Evaluation of various inclusion rates of organic zinc either as polysaccharide or proteinate complex on the growth performance, plasma, and excretion of nursery pigs. J Anim Sci. 2004;82:1359-1366.

17. Pettigrew JE, Esnaola MA. Swine nutrition and pork quality: A review. J Anim Sci. 2001;79(E-suppl):E316-E342. 
Pigs need dietary phosphorus for normal body maintenance and growth. It is an essential element that is required in many physiological processes in the pig's body and thus sufficient amounts must be included in the diet. This element is abundant in most grains found in swine diets. However, only a small amount of phosphorus is utilized from grains, because the majority of the phosphorus exists in a form (phytate) that is not digestible in swine. The digestibility of phytate phosphorus can be increased when supplemental phytase is included in the diet.

\section{What is phytate?}

Phytate or phytic acid is the main storage form of phosphorus in grains and oil seeds. Pigs are unable to digest phytate, as they lack digestive enzymes that break it down. As a result, a substantial amount of phosphorus is excreted as waste, with only $14 \%$ of the total phosphorus bioavailable in corn and up to approximately $50 \%$ in wheat. ${ }^{1,2}$ Because phosphorus is an essential element, inorganic phosphorus, which is highly available, is typically supplemented in the diet to meet the pig's requirement. Phytate also has other antinutritive effects, as it is known to reduce the availability and utilization of other nutrients. ${ }^{3-5}$

\section{Phytase}

Phytase is an enzyme that specifically acts on phytate, breaking it down to release phosphorus in a form available to the animal. This greatly reduces the need for supplemental inorganic phosphorus and improves the nutritional value of feedstuffs. Phytase activity is expressed as phytase units or FTUs. One FTU is the activity of phytase required to liberate $1 \mu \mathrm{mol}$ of inorganic phosphorus per minute at $\mathrm{pH} 5.5$ from an excess of $15 \mathrm{M}$ sodium phytate at $37^{\circ} \mathrm{C}$. Unlike the nonstarch-polysaccharide-degrading enzymes, phytase is the only exogenous enzyme that has been consistently shown to be highly beneficial to pigs. ${ }^{6}$ The proven efficacy of phytase has resulted in worldwide acceptance and use in pig production. ${ }^{7}$

\section{What is phytase derived from?}

Some ingredients possess intrinsic phytase activity, which varies greatly among plant species. Corn and soybean meal contain negligible levels of phytase activity compared to wheat, which contains considerably higher levels of intrinsic phytase. ${ }^{8}$ The majority of phytase activity in cereal grains is found in the aleurone layers. ${ }^{9}$ However, this may be lost when ingredients are subjected to high temperatures, such as during the pelleting process. ${ }^{10}$ Commercially available exogenous phytases are commonly derived from either fungi or bacteria, such as Aspergillus niger and Escherichia coli, ${ }^{6}$ but can also be expressed in yeasts. ${ }^{11,12}$

\section{How much phytase should be added to pig diets?}

The amount of phytase needed in a diet depends on the dietary ingredients used and enzyme activity for the product to be used. However, it is important to note that differences in laboratory assays exist, as well as differences among company products, ie, 1 FTU of one product may not be equivalent to 1 FTU of the other. It is important to obtain from the supplier the actual amount of phosphorus release based on their claimed enzyme activity for accurate diet formulation. In general, manufacturers' recommended

\section{Fast facts}

Phytase is an enzyme that increases availability of phosphorus in pig diets.

Phytase lowers the amount of supplemental phosphorus required in the diet.

Because of improved dietary phosphorus utilization, less phosphorus is excreted in the manure.

Phytase is susceptible to degradation during extended storage periods.

levels of commercially available phytases can replace inorganic phosphorus levels by $0.12 \%$ in pig diets. As the amount of phytase added to a diet increases, the release of phosphorus from phytate also increases in a curvilinear fashion. ${ }^{13}$ This means that phosphorus release diminishes with each additional unit of phytase until additional dietary levels of phytase fail to result in a further response.

\section{What affects the efficacy of phytase?}

Several factors can influence the efficacy of phytase, including the amount of phytate in the diet, the amount of phytase added to the diet, and the type of phytase. Studies have shown greater responses to phytase in pigs fed diets that contain higher amounts of phytate. ${ }^{6}$ Phytase derived from $E$ coli bacteria is also more efficacious than the fungal phytases in terms of the amount of phosphorus released per unit of phytase, according to published data. ${ }^{14-16}$ However, analytical techniques being used to determine phosphorus release vary among commercial phytase manufacturers. Because of this, the amount of phosphorus released per unit of phytase may differ between two phytase products, as shown in a recent study using a standard assay procedure. ${ }^{17}$ Thus, depending on the assay used, different results of phytase activity may be reported.

Because phytase is a protein, it is susceptible to denaturation when subjected to excessive heat, such as during pelleting. This may be addressed by spraying liquid phytase onto the cooled pellets to maintain the stability of the enzyme. In addition, heat-stable phytases are available. Phytase is also sensitive to degradation when stored in premixes under high temperature and moisture conditions. Hence, proper storage procedures and frequent rotation of products containing phytase must be practiced. Phytase products should be stored only in cool, dark, dry areas. The manufacturer's recommendations should always be followed, especially when phytase is included in vitamins and trace-mineral premixes.

The calcium-to-phosphorus ratio (Ca:P) of the diet may affect the magnitude of response to phytase. Studies have shown that wider Ca:P can result in decreased absorption of phosphorus. ${ }^{18-20}$ Thus, a range of $1: 1$ to $1.25: 1 \mathrm{Ca}: \mathrm{P}$ is recommended.

\section{Nonphosphorus effect of phytase}

In some studies in which pigs were fed diets with adequate levels of available phosphorus supplemented with phytase, improvements in 
growth performance were still observed, ${ }^{6}$ suggesting that phytase has a positive effect on other nutrients, eg, increased digestibility of energy and amino acids. However, results of other studies ${ }^{21-23}$ are not in agreement, thus there is no justification for assigning a nutrient value (energy or amino acid digestibility) other than phosphorus release to phytase. Phytase does improve availability of calcium and other minerals in the diet. ${ }^{24}$ It should be noted that addition of phytase also results in an overall increase in energy value of the diet. The reason for this is that more corn is added to the diet as the amount of inorganic phosphorus (which has no energy value) is reduced.

\section{Summary}

Phytase is an enzyme that increases the digestibility of phytate phosphorus, which improves the overall availability of dietary phosphorus. The use of this enzyme as a feed additive in swine diets reduces the requirement for inorganic phosphorus supplementation. As inorganic phosphorus is replaced by corn or other grains in the diet formulation, the diet's overall energy content increases. Improved phosphorus utilization and reduced inorganic phosphorus in the diet result in less phosphorus excretion from pigs. Phytase also can increase availability of other minerals such as calcium. As phytase is sensitive to high temperature and humidity, proper storage and handling procedures should be followed to maintain the efficacy of the product. Heat stability of the product must also be considered when diets are pelleted.

\section{References}

1. National Research Council. Minerals. In: Nutrient Requirements of Swine. 10th ed. Washington, DC: National Academy Press; 1998:47-70.

2. Cromwell GL. The biological availability of phosphorus in feedstuffs for pigs. Pig News Inf. 1992;13:75N-78N.

3. Cheryan M. Phytic acid interactions in food systems. Crit Rev Food Sci Nutr. 1980;13:297-335.

4. Torre M, Rodriguez AR, Saura-Calixto F. Effects of dietary fiber and phytic acid on mineral availability. Crit Rev Food Sci Nutr. 1991;30:1-22.

5. Ravindran V, Cabahug S, Ravindran G, Bryden WL. Influence of microbial phytase on apparent ileal amino acid digestibility of feedstuffs for broilers. Poult Sci. 1999;78:699-706.

6. Selle PH, Ravindran V. Phytate-degrading enzymes in pig nutrition. Livest Sci. 2008;113:99-122.

7. Sheppy C. The current feed enzyme market and likely trends. In: Bedford MR, Partridge MM, eds. Enzymes in Farm Animal Nutrition. Wallingford, UK: CABI Publishing; 2001:1-10.

8. Eeckhout W, Depaepe M. Total phosphorus, phytate-phosphorus and phytase activity in plant feedstuffs. Anim Feed Sci Technol. 1994;47:19-29.

9. Oatway L, Vasanthan T, Helm JH. Phytic acid. Food Rev Int. 2001;17:419431.
10. Jongbloed AW, Kemme PA. Effect of pelleting mixed feeds on phytase activity and the apparent absorbability of phosphorus and calcium in pigs. Anim Feed Sci Technol. 1990;28:233-242.

11. Ciofalo V, Barton N, Kretz K, Baird J, Cook M, Shanahan D. Safety evaluation of a phytase, expressed in Schizosaccharomyces pombe, intended for use in animal feed. Reg Toxicol Pharmacol. 2003;37:286-292.

12. Pandey A, Szakacs G, Soccol CR, Rodriguez-Leon JA, Soccol VT. Production, purification and properties of microbial phytases. Bioresour Technol. 2001;77:203-214.

13. Kornegay ET. Digestion of phosphorus and other nutrients: the role of phytases and factors influencing their activity. In: Bedford MR, Partridge GG, eds. Enzymes in Farm Animal Nutrition. Wallingford, UK: CABI Publishing; 2001:237-271

*14. Augspurger NR, Gaines AM, Danielson JR, Southern LL. The phosphorus-releasing efficacy of an $E$. coli-derived phytase in young pigs is dose-dependent and is not affected by the addition of a lipid-based coating added for pelleting stability [Abstract \# T216]. J Anim Sci. 2007;85E-Suppl 1. Available at: http://adsa.asas.org/meetings/2007/abstracts/0301.PDF. Accessed 4 December 2009.

15. Adeola O, Sands JS, Simmins PH, Schulze H. The efficacy of an Escherichia coli-derived phytase preparation. J Anim Sci. 2004;82:2657-2666.

16. Kornegay ET, Qian H. Replacement of inorganic phosphorus by microbial phytase for young pigs fed on a maize-soyabean-meal diet. Br J Nutr. 1996;76:563-578.

17. Jones CK. Effects of Dietary Enzymes or Specialty Proteins on Nursery Pig Performance [master's thesis]. Manhattan, Kansas: Kansas State University; 2009.

18. Qian H, Kornegay ET, Conner DE Jr. Adverse effects of wide calcium: phosphorus ratios on supplemental phytase efficacy for weanling pigs fed two dietary phosphorus levels. J Anim Sci. 1996;74:1288-1297.

19. Liu J, Bollinger DW, Ledoux DR, Venum TL. Effects of dietary calcium: phosphorus ratios on apparent absorption of calcium and phosphorus in the small intestine, cecum, and colon of pigs. J Anim Sci. 2000;78:106-109.

20. Johnston SL, Williams SB, Southern LL, Bidner TD, Bunting LD, Matthews JO, Olcott BM. Effect of phytase addition and dietary calcium and phosphorus levels on plasma metabolites and ileal and total-tract nutrient digestibility in pigs. J Anim Sci. 2004;82:705-714.

21. Adeola O, Sands JS. Does supplemental dietary microbial phytase improve amino acid utilization? A perspective that it does not. J Anim Sci. 2003;81(14)(suppl 2):E78-E85.

22. Liao SF, Sauer WC, Kies AK, Zhang YC, Cervantes M, He JM. Effect of phytase supplementation to diets for weanling pigs on the digestibilities of crude protein, amino acids, and energy. J Anim Sci. 2005;83:625-633.

23. Pomar C, Gagne F, Matte JJ, Barnett G, Jondreville C. The effect of microbial phytase on true and apparent ileal amino acid digestibilities in growing-finishing pigs. J Anim Sci. 2008;86:1598-1608.

24. Kies AK, Kemme PA, Sebek LBJ, van Diepen JTM, Jongbloed AW. Effect of graded doses and a high dose of microbial phytase on the digestibility of various minerals in weaner pigs. J Anim Sci. 2006;84:1169-1175.

* Non-refereed reference. 